\title{
Penerapan Metode Konseling Behavioral Guna Meningkatkan Kedisiplinan Belajar Pada Siswa Kelas VIII. 3 SMP Negeri 1 Praya Tahun Pelajaran 2018/2019
}

\author{
Rohaniah \\ Guru Bimbingan Konsling SMPN 1 Praya
}

\begin{abstract}
Abstrak. Penelitian ini berdasarkan permasalahan: (a) Apakah Pembelajaran dengan Konseling Behavioral berpengaruh terhadap hasil belajar Bimbingan Konseling ? (b) Seberapa tinggi tingkat penguasaan materi pelajaran Bimbingan Konseling dengan diterapkannya metode pembelajaran Konseling Behavioral ? Tujuan dari penelitian ini adalah: (a) Untuk mengungkap pengaruh Pembelajaran dengan Konseling Behavioral terhadap hasil belajar Bimbingan Konseling . (b) Ingin mengetahui seberapa jauh pemahaman dan penguasaan mata pelajaran Bimbingan Konseling setelah diterapkannya Pembelajaran dengan Konseling Behavioral Penelitian ini menggunakan penelitian tindakan (action research) sebanyak tiga putaran. Setiap putaran terdiri dari empat tahap yaitu: rancangan, kegiatan dan pengamatan, refleksi, dan refisi. Sasaran penelitian ini adalah siswa Kelas VIII. 3 . Data yang diperoleh berupa hasil tes formatif, lembar observasi kegiatan belajar mengajar. Dari hasil analis didapatkan bahwa prestasi belajar siswa mengalami peningkatan dari siklus I sampai siklus III yaitu, siklus I (71\%), siklus II (93\%). Simpulan dari penelitian ini adalah metode pembelajaran Konseling Behavioral dapat berpengaruh positif terhadap motivasi belajar Siswa Kelas VIII . 3 serta model pembelajaran ini dapat digunakan sebagai salah satu alternative Bimbingan Konseling .
\end{abstract}

Kata Kunci: Metode Konseling behavioral, Kedisiplinan, Belajar

\section{PENDAHULUAN}

\section{Latar Belakang Masalah}

Pendidikan adalah sebuah aset yang penting di dalam kehidupan berbangsa dan bernegara, karena bagaimana pun tidak ada bangsa yang maju tanpa diiringi pendidikan yang bermutu.

Pendidikan yang berkualitas bukan hanya dilihat dari sejauh mana proses pengajarannya saja, Yusuf \& Juntika (2005:5) memaparkan ada tiga bidang pendidikan yang harus menjadi perhatian, diantaranya : 1). Bidang administrative dan kepemimpinan, 2). Bidang Intruksional dan kurikuler, 3). Bidang pembinaan siswa (Bimbingan dan Konseling).

$$
\text { Terkait dengan masalah }
$$
bimbingan dan konseling, terdapat banyak ragam teori dan pendekatan dalam pelaksanaan layanan bimbingan dan konseling, salah satunya adalah teori konseling behavioral, yang akan coba kami kupas satu persatu sehingga akan tampak sedikit kejelasan, dengan harapan kupasan materi yang kami sajikan bermanfaat bagi kita semua yang bergerak dalam dunia pendidikan.

Pendekatan konseling behavioral merupakan bentuk adaptasi dari aliran psikologi behavioristik, yang menekankan pada perilaku yang tampak, setiap aktivitas dari individu yang dapat diamati. Perkembangan konseling behavioral bertolak dari perkembangan aliran behavioristik yang menolak pandangan strukturalisme dan fungsionalisme tentang kesadaran, yang berpendapat bahwa mental, pikiran dan perasaan hendaknya ditemukan terlebih dahulu apabila perilaku 1 manusia ingin dipahami, pandangan inilah yang menjadi landasan munculnya teori introspeksi. Disiplin diartikan sebagai ketaatan pada peraturan. Dari sini semuanya bermula sebelum disiplin diterapkan perlu dibuat tata tertib atau peraturan yang

\section{benarbenar realistik.}

Dengan disiplin seseorang dituntun untuk berperilaku sesuai dengan aturan dan norma-norma yang berlaku di 
mana seseorang tersebut berada. Di setiap tempat terdapat berbagai macam aturan dan norma. Aturan dan norma di tempat yang satu berbeda pula dengan aturan dan norma yang berlaku di tempat lain, oleh karena itu setiap individu dituntut untuk selalu disiplin di manapun ia berada. Bila individu selalu disiplin dan mematuhi aturan dan norma yang berlaku maka individu tersebut akan terbiasa hidup teratur.

Dari latar belakang masalah tersebut, maka peneliti merasa terdorong untuk mengambil judul " Penerapan Metode Konseling Behavioral Guna Meningkatkan Kedisiplinan Belajar Siswa Pada Kelas VIII.3 SMP Negeri 1 Praya Tahun Pelajaran 2018/2019

\section{Rumusan Masalah}

Merujuk pada uraian latar belakang di atas, dapat dirumuskan masalah sebagai berikut: Apakah Pembelajaran dengan Konseling Behavioral berpengaruh terhadap hasil belajar Bimbingan Konseling siswa Sekolah SMP Negeri 1 Praya Kelas VIII. 3 tahun pelajaran 2018/2019?

\section{Tujuan Penelitian}

Berdasar atas rumusan masalah di atas, maka tujuan dilaksanakan penelitian ini adalah: untuk mengungkap pengaruh Pembelajaran Konseling Behavioral dengan prestasi siswa Kelas VIII. 3 tahun pelajaran 2018/2019.

\section{Manfaat Penelitian}

Hasil dan temuan penelitian ini dapat memberikan informasi tentang Pembelajaran dengan Konseling Behavioral dalam pembelajaran Bimbingan Konseling oleh guru Kelas VIII. 3 tahun pelajaran 2018/2019 sehingga Siswa, dapat meningkatkan motiviasi belajar dan melatih sikap sosial untuk saling peduli terhadap keberhasilan siswa lain dalam mencapai tujuan belajar.

\section{LANDASAN TEORI DAN HIPOTESIS}

Pengertian Teori Konseling Behavioral

Konseling Behavioral adalah salah satu dari teori-teori konseling yang ada pada saat ini. Konseling behavioral merupakan bentuk adaptasi dari aliran psikologi behavioristik, yang menekankan perhatiannya pada perilaku yang tampak.
Pada hakikatnya konseling merupakan sebuah upaya pemberian bantuan dari seorang konselor kepada klien, bantuan di sini dalam pengertian sebagai upaya membantu orang lain agar ia mampu tumbuh ke arah yang dipilihnya sendiri, mampu memecahkan masalah yang dihadapinya dan mampu menghadapi krisis-krisis yang dialami dalam kehidupannya (Yusuf\&Juntika,2005:9).

Pengertian konseling tidak dapat dipisahkan dengan bimbingan karena keduanya merupakan sebuah keterkaitan. Muhamad Surya (1988:25) mengungkapkan bahwa konseling merupakan bagian inti dari kegiatan bimbingan secara keseluruhan dan lebih berkenaan dengan masalah individu secara Pribadi.

Juntika (2003:15) mengutip pengertian konseling dari ASCA (American School Conselor Assosiation ) sebagai berikut : Konseling adalah hubungan tatap muka yang bersifat rahasia, penuh dengan sikap penerimaan dan pemberian kesempatan dari konselor kepada klien, konselor mempergunakan pengetahuan dan keterampilannya untuk membantu kliennya dalam mengatasi maslah-masalahnya.

Sedangkan pengertian behavioral/ behaviorisme adalah satu pandangan teoritis yang beranggapan, bahwa persoalan psikologi adalah tingkah laku, tanpa mengaitkan konsepsi-konsepsi mengenai kesadaran dan mentalitas (JP.Chaplin, 2002:54). Aliran Behaviorisme ini berkembang pada mulanya di Rusia kemuadian diikuti perkembangannya di Amerika oleh JB. Watson (1878-1958). Dari pengertian koneling dan behaviorisme yang dipaparkan di atas kita dapat menarik kesimpulan bahwa yang dimaksud dengan konseling behavioral adalah sebuah proses konseling (bantuan) yang diberikan oleh konselor kepada klien dengan menggunakan pendekatan-pendekatan tingkah laku (behavioral), dalam hal pemecahan masalahmasalh yang dihadapi serta dalam penentuan arah kehidupan yang ingin dicapai oleh diri klien. Menurut Krumboltz\& Thoresen (Surya, 1988:187) konseling behavioral adalah suatu proses membantu orang untuk belajar memecahkan masalah interpersonal, emosional, dan keputusan tertentu. 


\section{Sejarah Konseling Behavioral}

Konseling berkembang pertama kali di Amerika yang dipelopori oleh Jesse B. Davis tahun 1898 yang bekerja sebagai konselor sekolah di Detroit (Surya,1988:39). Banyak factor yang mempengaruhi perkembangan konseling, salah satunya adalah perkembangan yang terjadi pada kajian psikologis, Surya (1988:42) mengungkapkan bahwa kekuatan-kekuatan tertentu dalam lapangan psikologis telah mempengaruhi perkembangan konseling baik dalam konsep maupun teknik. Aliran-aliran yang muncul dalam lapangan psikologi memberikan pengaruh yang cukup besar terhadap perkembangan konseling, diantara aliranaliran psikologi yang cukup memberikan pengaruh terhadap perkembangan konseling adalah sebagai berikut ; aliran strukturalisme (Wundt), Fungsionalisme James), dan Behaviorisme (Watson).

Perkembangan

koseling

behavioral bertolak dari perkembanngan aliran behavioristik dalam perkembangan psikologi yang menolak pendapat aliran strukturalisme yang berpendapat bahwa mental, pikiran dan perasaan hendaknya ditemukan terlebih dahulu bila perilaku manusia ingin difahami, maka munculah teori introspeksi.

Aliran Behaviorisme menolak metode introspeksi dari aliran strukturalisme dengan sebuah keyakinan bahwa menurut para behaviorist metode introspeksi tidak dapat menghasilkan data yang objektif, karena kesadaran menurut para behaviorist adalah sesuatu yang Dubios, yaitu sesuatu yang tidak dapat diobservasi secara langsung, secara nyata (Walgito,2002:53). Bagi aliran Behaviorisme yang menjadi focus perhatian adalah perilaku yang tampak, karena persoalan psikologi adalah tingkah laku, tanpa mengaitkan konsepsi-konsepsi mengenai kesadaran dan mentalitas.

Dari hasil eksperimennya Thorndike menetapkan ada tiga macam hokum yang sering disebut dengan hukum primer dalam hal belajar, tiga hokum tersebut adalah : (1) Hukum Kesiap sediaan the law of readiness, (2) Hukum Latihan The Law of exercise,(3)Hukum efek The Law of effect The law of readiness, adalah salah satu factor penting, karena dalam proses belajar yang baik organisme harus mempunyai kesiapsediaan, karena tanpa adanya kesiapsediaan dari organisme yang bersangkutan maka hasil belajarnya tidak akan baik.

Sedangkan hokum latihan the law of exercise Thorndike mengemukakan dua aspek yang terkandung di dalamnya yaitu ; 1). The law of use, 2). The law of disuse. The law of use adalah hukuk yang menyatkan bahwa hubungan atau koneksi antara stimulusrespons akan menjadi kuat apabila sering digunakan. The law of disuse; adalh hokum yang menyatakan bahwa koneksi antara stimulus-respons akan menjadi lemah apabila tidak latihan.

Mengenai hukum efek Thorndike berpendapatkan bahwa memperkuat atau memperlemah hubungan stimulus-respons, tergantung pada bagaiman hasil dari respons yang bersangkutan (Walgito,2002:56).

Perilaku respons; perilaku respons adalah perilaku alami, perilaku ini merupakan respons langsung atas stimulus, perilaku ini bersifat reflektif. Perilaku ini sama halnya dengan istilah aktivitas reflektif dalam kondisioning klasik dari Pavlov. Perilaku operan; perilaku ini lebih bersifat spontan, perilaku yang muncul bukan ditimbulkan oleh stimulus, melainkan ditimbulkan oleh organisme itu sendiri. Terdapat dua prinsip umum dalam teori pengkondisian operan yang dipaparkan olegh Skinner, dua prinsip tersebut adalah ; 1). Setiap respons yang disertai dengan Reward (sebagai reinforcement stimuli) akan cenderung diulangi, dan 2). Reward atau reinforcement stimuli akan meningkatkan kecepatan atau rate terjadinya respons (Walgito,2002:57).

\section{Konsep Dasar Teori Konseling Behavioral}

Dalam pembahasan sebelumnya telah dibahas tentang konsep dasar konseling adalah membantu, sedangkan konsep dasar dari behaviorisme adalah prediksi\&control atas perilaku manusia yang tampak.

Muhamad Surya (1988:186) memaparkan bahwa dalam konsep behavioral, 
perilaku manusia merupakan hasil belajar, sehingga dapat diubah dengan memanipulasi dan mengkreasi kondisi-kondisi belajar. Pada dasarnya, proses konseling merupakan suatu penataan proses atau pengalaman belajar untuk membantu individu untuk mengubah perilakunya agar dapat memecahkan masalahnya.

Hal yang paling mendasar dalam konseling behavioral adalah penggunaan konsep-konsep behaviorisme dalam pelaksanaan konseling, seperti konsep reinforcement yang nerupakan bentuk adaptasi dari teori pengkondisian klasik Pavlov, dan pengkondisiaan operan dari Skinner. Menurut Surya (1988:186) menyatakan bahwa ada tiga macam hal yang dapat memberi penguatan yaitu : 1). Positive reinforcer, 2).Negative reinforcer, 3).no consequence and natural stimuli.

Hubungan Konselor -Klien

Yang menjadi perhatian utama konselor behavioral adalah perilaku yang tampak, dengan alasan ini banyak asumsi yang berkembang tentang pola hubungan konselor-klien lebih manupulatif- mekanistik dan sangat tidak Pribadi, namun seperti dituturkan Rosjidan (1988:243) salah satu aspek yang essensial dalam terapi behavioral adalah proses penciptaan hubungan Pribadi yang baik.

Untuk melihat hubungan konselor-klien dalam seting konseling behavioral dapat kita perhatikan dari proses konseling behavioral. Proses konseling behavioral yaitu sebuah proses membantu orang untuk belajar memecahkan masalah interpersonal, emosional, dan keputusan tertentu. Jika kita perhatikan lebih lanjut, pendekatan dalam konseling behavioral lebih cenderung direktif, karena dalam pelaksanaannya konselor-lah yang lebih banyak berperan.

Metode-Metode Konseling Behavioral

Terdapat beberapa pendekatan atau metode yang diterapkan dalam koneling behavioral. Krumboltz (Surya, 1988:188) memberikan empat kategori pendekatan konseling behavioral : 1). operant learning, 2).social modeling, 3). Cognitive leraning, 4). Emotional learning.
Kedisiplinan

Pengertian Kedisiplinan

Menurut Sobur (1985, h. 64), kedisiplinan adalah suatu proses dari latihan atau belajar yang bersangkut paut dengan pertumbuhan dan perkembangan. Selanjutnya, menurut Hurlock (1991, h.82), disiplin berasal dari kata "disciple" yang berarti bahwa seseorang belajar secara suka rela mengikuti seorang pemimpin. Orang tua maupun guru merupakan pemimpin dan anak merupakan murid yang belajar dari mereka cara hidup menuju ke hidup yang berguna dan bahagia. Menurut Abu (1989, h.30), kedisiplinan siswa di sekolah adalah kepatuhan siswa terhadap peraturan-peraturan yang telah ditetapkan oleh sekolah. Pendapat lain juga dikemukakan oleh Soekanto (1996, h.80) yang menyebutkan bahwa kedisiplinan merupakan suatu keadaan dimana perilaku berkembang dalam diri seseorang yang menyesuaikan diri dengan tertib pada keputusan, peraturan, dan nilai dari suatu pekerjaan.

Sobur (1985, h.64) berpendapat bahwa seseorang dapat dikatakan disiplin bila ia sudah berhasil dan bisa mengikuti dengan sendirinya tokoh-tokoh yang telah menetapkan aturan tersebut. Tokoh-tokoh itu antara lain adalah orang tua dan guru yang mengarahkan agar kehidupan menjadi lebih bermanfaat bagi diri sendiri dan menimbulkan perasaan bahagia. Lebih lanjut Sobur juga mengatakan bahwa tujuan dari disiplin adalah untuk membuat seseorang terlatih dan terkontrol dengan mengajarkan kepada mereka bentuk-bentuk tingkah laku yang pantas dan yang tidak pantas atau yang masih asing bagi mereka. Selain itu disiplin juga sebagai pengarahan diri sendiri tanpa pengaruh atau pengendalian diri dari luar.

Sekolah yang baik mutunya akan menciptakan suasana pengajaran dan suasana kelas yang menyejukkan, menimbulkan motivasi belajar, penuh perhatian dan rasa aman, berlaku adil dan adanya keteraturan yang dapat memelihara kedisiplinan yang cukup tinggi akan sangat berpengaruh terhadap pembentukkan sikap dan perilaku kehidupan pendidikan anak dan pola pikirnya dalam menghadapi karier. Namun, usaha 
untuk menciptakan disiplin pada siswa-siswa tetunya membutuhkan waktu yang lama dan harus ditetapkan secara bijaksana serta berlaku pada semua orang yang berada dilingkungan sekolah mulai dari kepala sekolah, guru-guru dan para siswa dengan sanksi-sanksi yang diberikan secara bijaksana. (Abu, 1989, h.30)

Peraturan-peraturan yang dibuat harus jelas dan dapat dimengerti, sehingga secara logis seseorang dapat mengikutinya bukan hanya dalam arti mematuhi otoritas, melainkan juga mengerti bahwa pelanggaran peraturan dapat merugikan kepentingan bersama dan diri sendiri. (Dreikurs dan Cassel, 1986,h.87). Dengan disiplin siswa akan memiliki kecakapan mengenai cara belajar yang baik dan disiplin juga merupakan suatu proses pembentukan watak yang baik. Dengan adanya peraturan yang ditetapkan, maka siswa akan mengarahkan diri sehingga menghasilkan kedisiplinan. (Gie, 1988, h.59).

Dari beberapa pendapat di atas, dapat ditarik kesimpulan bahwa kedisiplinan adalah seseorang yang dengan sukarela berperilaku mengikuti, menyesuaikan diri dengan tertib pada aturan-aturan yang berlaku untuk mencapai kehidupan yang lebih berguna dan bahagia.

Prestasi Belajar

Secara sederhana belajar dapat diartikan sebagai proses perubahan dari belum mampu menjadi sudah mampu yang terjadi dalam jangka waktu tertentu. Perubahan itu harus secara relatif menetap dan tidak hanya terjadi pada perilaku yang saat ini nampak tetapi juga pada perilaku yang mungkin terjadi di masa mendatang. (Irwanto, dkk, 1991, h. 105). Selanjutnya, Morgan ( 1975, h. 136) mendefinisikan belajar sebagai perubahan tingkah laku yang sifatnya relatif menetap dan terjadinya sebagai hasil dari pengalaman atau latihan.

Menurut Winkel (1996, h. 475) prestasi belajar adalah hasil yang telah dicapai seseorang dalam belajar. Dalam pendidikan formal, belajar menunjukkan adanya perubahan yang sifatnya poitif sehingga pada tahap akhir akan didapat keterampilan, kecakapan dan pengetahuan baru. Hasil dari proses balajar tersebut tercermin dalam prestasi belajarnya. Gambaran mengenai prestasi belajar tersebut biasanya dapat diperoleh melalui raport sekolah yang dibagikan pada waktu-waktu tertentu. (Murjono, 1996, h. 174).

Menurut Poerwadarminta (1990, h. 260), prestasi belajar adalah hasil yang dicapai seorang siswa dalam jangka waktu tertentu dan tercatat dalam buku raport sekolah. Menurut Sukadji (2000, h. 20) bahwa prestasi belajar adalah hasil yang telah dicapai seseorang dalam belajar. Dalam belajar, sikap seseorang selalu mempunyai harapan untuk mencapai hasil yang optimal demi tercapainya prestasi belajar yang tinggi. Prestasi belajar juga sering dikatakan sebagai hasil dari perbuatan belajar yang melukiskan taraf kemampuan seseorang setelah belajar dan berlatih dengan sengaja sehingga menimbulkan perubahan tingkah laku ke arah yang lebih maju.

\section{Faktor-Faktor Yang Mempengaruhi Prestasi Belajar}

Prestasi belajar ditentukan oleh beberapa faktor. Menurut Azwar (2000, h. 165), faktor-faktor yang mempengaruhi prestasi belajar adalah: a) Faktor fisik yang meliputi panca indera dan kondisi fisik umum, b)Faktor psikologis yang meliputi kemampuan non kognitif dan kemampuan kognitif. Kemampuan non kognitif terdiri dari minat, motivasi, dan variabel-variabel kepribadian. Sedangkan kemampuan kognitif terdiri dari kemampuan khusus (bakat) dan kemampuan umum (inteligensi), c)Faktor sosial dan budaya yang meliputi lingkungan keluarga, lingkungan sekolah, lingkungan masyarakat, lingkungan kelompok, adat istiadat, ilmu pengetahuan, teknologi dan kesenian.

\section{Metodologi Penelitian}

Penelitian ini merupakan penelitian tindakan (action research), karena penelitian dilakukan untuk memecahkan masalah pembelajaran di kelas. Penelitian ini juga termasuk penelitian deskriptif, sebab menggambarkan bagaimana suatu teknik pembelajaran diterapkan dan bagaimana hasil yang diinginkan dapat dicapai..

Penelitian tindakan telah mulai berkembang sejak perang dunia kedua. Oleh 
sebab itu, terdapat banyak pengertian tentang PTK. Istilah PTK dideferensiasi dari pengertianpengertian berikut.

Kemmis (1992): Action research as a form of self-reflective inquiry undertaken by participants in a social (including educational) situation in order to improve the rationality and justice of (a) their on social or educational practices, (b) their understanding of these practices, and (c) the situations in which practices are carried out. McNeiff (2002): action research is a term which refer to a practical way of looking at your own work to sheck that it is you would like it to be. Because action researchis done by you, the practitioner, it is often referred to as practitioner based research; and because it involves you thinking about and reflecting on your work, it can also be called a form of selfreflective practice.

Berdasarkan penjelasan Kemmis dan McNeiff tersebut, dapat dicermati pengertian PTK secara lebih rinci dan lengkap. PTK didefinisikan sebagai suatu bentuk kajian yang bersifat reflektif oleh pelaku tindakan. Tindakan tersebut dilakukan untuk meningkatkan kemantapan rasional dari tindakan-tindakan mereka dalam melaksanakan tugas sehari-hari, memperdalam pemahaman terhadap tindakantindakan yang dilakukan, serta memperbaiki kondisi di mana praktik-praktik pembelajaran tersebut dilakukan. Untuk mewujudkan tujuan-tujuan tersebut, PTK dilaksanakan dalam proses berdaur (cyclical) yang terdiri dari empat tahapan, planing, action, observation/evaluation, dan reflection.

Dalam penelitian tindakan ini menggunakan bentuk guru sebagai peneliti, penanggung jawab penuh penelitian ini adalah guru. Tujuan utama dari penelitian tindakan ini adalah untuk meningkatkan hasil pembelajaran di kelas dimana guru secara penuh terlibat dalam penelitian mulai dari perencanaan, tindakan, pengamatan, dan refleksi.

Dalam penelitian ini peneliti tidak bekerjasama dengan siapapun, kehadiran peneliti sebagai guru di kelas sebagai pengajar tetap dan dilakukan seperti biasa, sehingga siswa tidak tahu kalau diteliti.
Dengan cara ini diharapkan didapatkan data yang objektif

\section{Tempat, Waktu dan Subyek Penelitian}

Penelitian ini bertempat di SMP

Negeri 1 Praya pada bulan Agustus sampai bulan Oktober semester ganjil tahun pelajaran 2018/2019 pada siswa kelas VIII. 3.

\section{Rancangan Penelitian}

Sesuai dengan jenis penelitian yang dipilih, yaitu penelitian tindakan, maka penelitian ini menggunakan model penelitian tindakan dari Kemmis dan Taggart (dalam Sugiarti, 1997: 6), yaitu berbentuk spiral dari siklus yang satu ke siklus yang berikutnya. Setiap siklus meliputi planning (rencana), action (tindakan), observation (pengamatan), dan reflection (refleksi). Langkah pada siklus berikutnya adalah perncanaan yang sudah direvisi, tindakan, pengamatan, dan refleksi. Sebelum masuk pada siklus 1 dilakukan tindakan pendahuluan yang berupa identifikasi permasalahan. Siklus spiral dari tahap-tahap penelitian tindakan kelas dapat dilihat pada gambar berikut.

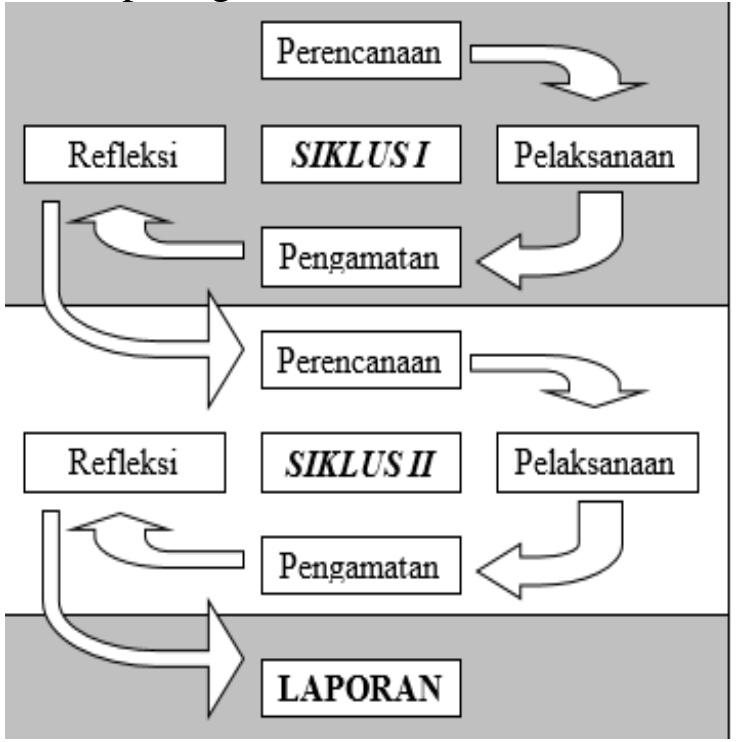

Gambar 3.1 Alur PTK.

Perencanaan Tindakan

Penelitian ini dilakukan dengan metode penelitian tindakan sekolah yang berlangsung selama 2 siklus. Masing-masing siklus terdiri dari tahapan perencanaan, pelaksanaan, observasi dan refleksi.

\section{Teknik Analisa Data}

Untuk mengetahui efektivan suatu metode dalam kegiatan pembelajaran perlu diadakananalisa data. Pada penelitian ini 
menggunakan teknik analisa deskriptif kualitatif, yaitu suatu metode penelitian yang bersifat menggambarkan kenyataan atau fakta sesuai dengan data yang diperoleh dengan tujuan untuk mengetahui prestasi belajar yang dicapai sisw juga untuk memperoleh respon siswa terhadap kegiatan pembelajaran serta aktivitas siswa selama proses pembelajaran.

Untuk menganalisis tingkat keberhasilan atau persentase keberhasilan siswa setelah proses belajar mengajar setiap putarannya dilakukan dengan cara memberikan evaluasi berupa tes praktek pada setiap akhir putaran, Analisa ini dihitung dengan menggunakan statistic sederhana yaitu:

Untuk menilai tes praktek

Peneliti melakukan penjumlahan nilai yang diperoleh siswa yang selanjutnya dibagi dengan jumlah siswa yang ada di kelas tersebut sehingga diperlukan rata-rata tes praktek dapat dirumuskan

$$
\bar{X}=\frac{\sum X}{\sum N}
$$

Dengan

$$
\begin{array}{ll}
\frac{\bar{X}}{X}= & \text { Nilai rata-rata } \\
\sum_{\text {siswa }} X & =\text { Jumlah semua nilai } \\
\sum N & =\quad \text { Jumlah siswa }
\end{array}
$$

Untuk Ketercapaian belajar

Ada dua kategori Ketercapaian belajar yaitu secara perorangan dan secara klasikal. Berdasarkan petunjuk pelaksanaan belajar mengajar kurikulum 1994 (Depdikbud, 1994) yaitu siswa telah tuntas belajar bila di kelas tersebut mendapat $85 \%$ yang telah mencapai daya serap dari sama dengan.

Untuk menghitung persentase Ketercapaian belajar digunakan rumus sebagai berikut:

$$
P=\frac{\sum \text { Siswayangtuntasbelajar }}{\sum \text { siswa }} \times 100 \%
$$

Untuk lembar observasi

Lembar observasi pengolahan metode penampilan dan eksperimen untuk menghitung lembar observasi pengolahan metode penampilan dan eksperimen digunakan rumus sebagai berikut:

$$
\bar{X}=\frac{P_{1}+{ }_{-} P_{2}}{2}
$$

Dimana :

$$
\begin{array}{lll}
\mathrm{P}_{1} & = & \text { pengamatan } 1 \mathrm{dan} \\
\mathrm{P}_{2} & = & \text { pengamat } 2
\end{array}
$$

Lembar observasi aktivitas guru dan siswa Untuk menghitung lembar observasi aktivitas guru dan siswa digunakan rumus sebagai berikut:

$$
\%=\frac{\bar{X}}{\sum X} x 100 \%
$$

dengan

$$
\bar{X}=\frac{\text { jumlahhasipengamatan }}{\text { jumlahpengamat }}=\frac{P_{1}+P_{2}}{2}
$$

Dimana:

$$
\begin{array}{lll}
\frac{\%}{X} & = & \text { persentase angket } \\
\sum \bar{X} & = & \text { Rata-rata } \\
\mathrm{P} 1 & = & \text { Pengamah Rata-rata } 1
\end{array}
$$

$\mathrm{P} 2=$ Pengamat 2

Untuk menghitung persentase angket digunakan rumus sebagai berikut:

$$
P=\frac{Z}{n}
$$

Dimana

$$
\begin{aligned}
\mathrm{P} & =\text { Persentase } \\
\mathrm{Z} & =\text { Alternatif jawaban }(\mathrm{A}, \mathrm{B}, \mathrm{C}, \mathrm{D}) \\
\mathrm{N} & =\text { Jumlah responden }
\end{aligned}
$$

Ranah Psikomotor

skala peniloaian yang digunakan sesuai dengan instrument yang telah direncanakan, yaitu antara 1-3 (1= kurang tepat, 2 = cukup dan 3 = tepat) untuk aspek penilaian. Hal ini berarti bahwa:

Skor minima yang diperoleh siswa adalah : 1 x $4=4$

- Skor maksimal yan diperoleh siswa adalah : 3 × $4=12$

- $\quad$ Medium skor adalah $: \frac{(4+12)}{2}=8$

- Dibuat rentang skor dan dikonversi menjadi nilai rapor sebagai pedoman penilaian.

Tabel 3.1 Pedoman Penilaian Ranah

psikomotor 


\begin{tabular}{|l|l|l|l|}
\hline & skor & Rapor & \\
\hline 1 & $11-12$ & A & Baik sekali \\
2 & $9-10$ & B & Baik \\
3 & $7-8$ & C & Cukup \\
4 & $5-6$ & K & Kurang \\
5 & $3-4$ & KS & Kurang sekali \\
\hline
\end{tabular}

Mutu Pembelajaran dikatakan baik apabila siswa yang mendapat nilai diatas 70 mencapai 85\% atau lebih dari keseluruhan siswa

\section{Hasil Penelitian Dan Pembahasan}

\section{Siklus I.}

Tahap Perencanaan

Pada tahap ini peneliti mempersiapkan pembelajaran yang terdiri dari rencana pelajaran 1 , soal tes 1 dan alatalat pengajaran yang mendukung. Selain itu juga dipersiapkan lembar observasi dan aktivitas siswa.

Tahap kegiatan dan Pelaksanaan

Pelaksanaan kegiatan belajar mengajar untuk siklus I dilaksanakan pada tanggal 26 Agustus 2018 di Kelas VIII.3 dengan jumlah siswa 32 siswa. Adapun proses belajar mengajar mengacu pada rencana pelajaran yang telah dipersiapkan. Pengamatan (observasi) dilaksanakan bersamaan dengan pelaksanaan belajar mengajar.

Pada akhir proses belajar mengajar siswa diberi tes I dengan tujuan untuk mengetahui keberhasln siswa dalam proses layanan konseling yang telah dilakukan. dari hasil analisis data dijelaskan bahwa siswa yang nilai skor diatas minimal (75) adalah sebesar $71 \%$.

Refleksi

Dalam pelaksanaan kegiatan belajar mengajar diperoleh informasi dari hasil pengamatan sebagai berikut; 1) Guru kurang baik dalam memotivasi siswa dan dalam menyampaikan layanan konseling, 2) Guru kurang baik dalam pengelolaan waktu, 3) Siswa kurang bisa antusias selama layanan.

Revisi

Pelaksanaan kegiatan layanan konseling pada siklus I ini masih terdapat kekurangan, sehingga perlu adanya revisi untuk dilakukan pada siklus berikutnya; 1) Guru perlu lebih terampil dalam memotivasi siswa dan lebih jelas dalam menyampaikan tujuan pembelajaran. Dimana siswa diajak untuk terlibat langsung dalam setiap kegiatan yang akan dilakukan, 2) Guru perlu mendistribusikan waktu secara baik dengan menambahkan informasi-informasi yang dirasa perlu dan memberi catatan, 3) Guru harus lebih terampil dan bersemangat dalam memotivasi siswa sehingga siswa bisa lebih antusias.

\section{Siklus II}

Tahap perencanaan

Pada tahap ini peneliti mempersiapkan pembelajaran yang terdiri dari rencana layanan konseling 2 , soal tes 2 dan alat-alat pengajaran yang mendukung. Selain itu juga dipersiapkan lembar observasi dan aktivitas siswa.

Tahap kegiatan dan pelaksanaan

Pelaksanaan kegiatan belajar mengajar untuk siklus II dilaksanakan pada tanggal 5 September 2018 di Kelas VIII 3 dengan jumlah siswa 32 siswa. Dalam hal ini peneliti bertindak sebagai pengajar. Adapun proses belajar mengajar mengacu pada rencana pelajaran dengan memperhatikan revisi pada siklus I, sehingga kesalahan atau kekuarangan pada siklus I tidak terulang lagi pada siklus II.

Pengamatan (observasi) dilaksanakan bersamaan dengan pelaksanaan belajar mengajar. Sebagai pengamat adalah peneliti dibantu oleh seorang guru ( IPA Terpadu )

Pada akhir proses belajar mengajar siswa diberi tes Psikomotor II dengan tujuan untuk mengetahui tingkat keberhasilan siswa dalam proses belajar mengajar yang dilakukan. Instrument yang digunakan adalah tes praktek II. serta memperbaiki kondisi di mana praktik-praktik pembelajaran tersebut dilakukan, adapun hasil penelitian pada siklus II adalah sebagai berikut: dari analisis data tersebut dapat dijelaskan bahwa siswa yang nilai skor diatas minimal $(75 \%)$ adalah sebesar $93 \%$.

Refleksi

Dalam pelaksanaan kegiatan belajar mengajar diperoleh informasi dari hasil pengamatan sebagai berikut; 1) guru sudah baik dalam memotivasi siswa dan dalam menyampaikan layanan konseling, 2) guru sudah bisa dengan baik dalam pengelolaan waktu, 3) Siswa mulai antusias selama layanan konseling. 
Revisi

Pelaksanaan kegiatan bimbingan konseling pada siklus II ini sudah berjalan dengan baik dan mendapatkan perubahan yang signifikan dalam kedisiplinan guru di dalam kelas berupa pelaksanaan layanan konseling.

\section{Pembahasan}

Melalui hasil penelitian ini menunjukkan bahwa pemberian layanan dengan methode reinforcement memiliki dampak positif dalam meningkatkan motivasi belajar siswa. Hal ini dapat dilihat dari semakin mantapnya pemahaman siswa terhadap materi yang disampaikan guru (Ketercapaian belajar meningkat dari siklus I, dan II) untuk ranah psikomotor yaitu siklus I (71\%), siklus II (93\%) pada siklus II Ketercapaian nilai siswa secara klasikal.

Kemampuan Guru dalam Mengelola Pembelajaran

Berdasarkan analisis data, diperoleh aktivitas siswa dalam proses belajar mengajar dengan menerapkan metode reinforcement dalam setiap siklus mengalami peningkatan. Hal ini berdampak positif terhadap prestasi belajar siswa yaitu dapat ditunjukkan dengan meningkatnya nilai rata - rata siswa pada setiap siklus yang terus mengalami peningkatan

Aktivitas Siswa dalam Pembelajaran

Berdasarkan analisis data, diperoleh aktivitas siswa dalam proses pembelajaran dengan model pembelajaran paling dominan adalah belajar dengan sesama anggota kelompok, mendengarkan/memperhatikan penjelasan guru dan diskusi antara siswa/antara siswa dengan guru. Jadi dapat dikatakan bahwa aktivitas siswa dapat dikategorikan aktif.

Sedangkan untuk aktivitas guru selama pembelajaran telah melaksanakan langkah-langkah metode reinforcement dengan baik. Hal ini terlihat dari aktivitas guru yang muncul di antaranya aktivitas membimbing dan mengamati siswa dalam mempraktikkan hasil pembelajaran , menjelaskan/melatih menggunakan alat, memberi umpan balik dalam prosentase untuk aktivitas di atas cukup besar.

\section{Simpulan}

Dari hasil kegiatan pembelajaran yang telah dilakukan selama dua siklus dan berdasarkan seluruh pembahaan serta analisis yang telah dilakukan dapat disimpulkan sebagai berikut; 1) Layanan Bimbingan Konseling dengan metode ini memiliki dampak positif dalam meningkatkan motivasi belajar siswa yang ditandai dengan peningkatan Ketercapaian nilai siswa dalam setiap siklus, yaitu siklus I (71\%), dan siklus II $(93 \%), 2)$ Penerapan metode layanan bimbingan konseling ini mempunyai pengaruh positif, yaitu dapat meningkatkan motivasi belajar siswa yang ditunjukkan dengan rata-rata jawaban siswa yang menyatakan bahwa siswa tertarik dan berminat dengan metode pembelajaran ini sehingga mereka menjati termotivasi untuk belajar.

\section{DAFTAR PUSTAKA}

Aqib,Zainal dkk. 2008. PTK untuk Guru SD, SLB, dan TK. Bandung : Yrama Widya

Arikunto, Suharsimi.2009. PTK (Penelitian Tindakan Kelas). Jakarta : Bumi Aksara.

Atkinson, et.al. 1996. Pengantar Psikologi (terj Dharma, Agus.) Jakarta : Erlangga

Chaplin, JP. 2002. Kamus Lengkap Psikologi (terj. Kartono, Kartini). Jakarta : Raja

Grapindo

Rosjidan. 1988. Pengantar Teori-teori Konseling. Jakarta: Departemen Pendidikan dan

Kebudayaan, Dirjen DIKTI

Surya, Muhamad. 1988. Dasar-dasar Konseling Pendidikan (Teori\&Konsep).

Yogyakarta : Penerbit Kota Kembang.

Yusuf, Syamsu\&Juntika, Nurihsan. Landasan

Bimbingan dan Konseling.

Bandung: Rosdakaraya.

Walgito,Bimo. 2002. Pengantar Psikologi. Yogyakarta : Penerbit Andi 